\title{
Supporting THE RATIONALE BEHIND THE HATCH- WAXMAN ACT AND PATENT LAW: HOW REVERSE PAYMENT SETTLEMENTS UNDER FTC V. ACTAVIS, INC. CAN Be PRocompetitive
}

\author{
Andrew E. Podgorny*
}

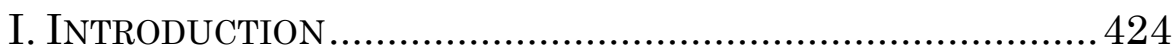

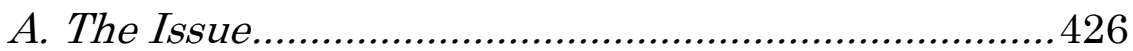

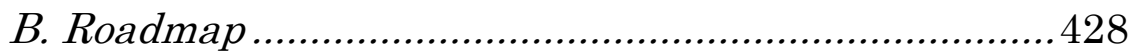

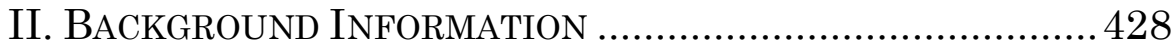

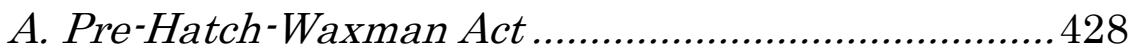

B. The Hatch-Waxman Act: A Compromise for Pioneer and Generic Manufacturers ....................................430

C. The Hatch-Waxman Act and Reverse Payment Settlements ...........................................................432

D. Alternative Methods to Analyze Reverse Payment Settlements........................................................434

1. The Third Circuit: The Quick Look Rule of Reason...436

2. The Eleventh Circuit: Scope of Patent Test.............436

E. The Circuit Split and Supreme Court Decision ........437

1. In re K-Dur Antitrust Litigation ..............................437

2. FTC v. Watson Pharmaceuticals Inc.......................439

3. FTC v. Actavis, Inc..............................................440

F. What is the Rule of Reason?...................................442

G. Congress Addresses Reverse Payment Settlements... 443

III. ANALYSIS: THE RESIDUAL EFFECT OF ACTAVIS AND

IMPORTANCE OF CRAFTING PRO-COMPETITIVE

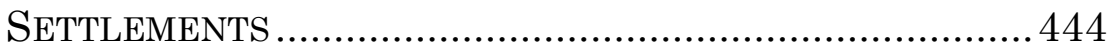

A. Impact of Using Rule of Reason Analysis.................. 444

1. Effect of Antitrust Laws: How Consumers Benefit.. 444

2. Effect of Antitrust Laws: Different Affect on Drug

Manufacturers.........................................................449

B. Complying with the Actavis Framework: Crafting Procompetitive Reverse Payment Settlements ........452

* J.D. Candidate, 2015, Indiana University Robert H. McKinney School of Law; B.S., 2011, Indiana University-Bloomington. 
1. What Type of Payments Implicate the Actavis

Analysis

2. Market Power

3. Relevant Market.

4. Redeeming Virtues...

5. Size of Monetary Payments

6. Time Frame for Generic Entry.

7. Strength of Patent

8. Venue

9. Ability to Explain 464

IV. Policy ReCOMmendation: How REVERSE PAYMENT SeTtlements Support THE InTENT OF PATENT LAW AND THE HATCH-WAXMAN ACT

V. CONCLUSION 468

\section{INTRODUCTION}

John's family has come to visit him at the nursing home. His grandchildren, bursting with excitement, come running into the room and jump up to hug their grandfather, only to be greeted with, "Who might you be?" John suffers from Alzheimer's disease, which causes him memory loss and also affects his intellectual abilities used in daily life. ${ }^{1}$ Alzheimer's disease is one of many known ailments that has continued to perplex scientists for over a century and, to this day, has no cure.

ABC Corporation ("ABC") is attempting to develop a new drug that will revolutionize medical treatment for people suffering from Alzheimer's disease. ABC's main business includes research, development, and marketing of new pharmaceutical drugs. Recently, due in large part to complex research and numerous clinical trials, ABC has poured millions of dollars and years of research into Drug 23. Dr. White, the lead scientist for Drug 23, claims that if

1 See Alzheimer's Ass'n, What is Alzheimer's?, ALZ.ORG, https://www.alz.org/alzheimers_disease_what_is_alzheimers.asp (last visited Mar. 8, 2014). 
ABC is successful in its development of Drug 23, its scientists will have developed a cure for Alzheimer's disease. While $\mathrm{ABC}$ is taking a huge risk by expending a large amount of resources into a drug that may or may not pay any dividends, that risk is worthwhile because of the potential benefit to society and the financial windfall $\mathrm{ABC}$ will gain from the right to legally sell the drug at a monopolistic price ${ }^{2}$ by virtue of obtaining a patent.

After years of painstaking effort and near bankruptcy for ABC, Drug 23 has come to fruition. Drug 23 has accomplished exactly what it set out to do, cure Alzheimer's disease. Wanting to sell its product, $\mathrm{ABC}$, the pioneer manufacturer, files a New Drug Application ${ }^{3}$ ("NDA") with the Food and Drug Administration ("FDA"). Thereafter, $\mathrm{ABC}$ receives approval from the FDA and begins marketing Drug 23. ABC's stock price skyrockets, mostly due to a large uptick in revenue and profit resulting from Drug 23 being sold at a monopolistic price.

A few years down the line, XYZ Corporation ("XYZ") plans to bring Drug 70 to the market, a drug equivalent to ABC's Drug 23. XYZ does not develop new drugs like ABC; instead, XYZ focuses its business on bringing generic equivalents to the market. In order to be able to sell Drug 70, XYZ, the generic manufacturer, files an Abbreviated New Drug Application" ("ANDA") with the FDA certifying that ABC's patent is either invalid or will not be infringed by XYZ. ${ }^{5}$ This process of certification is necessary to show that XYZ will not infringe the patent granted to ABC. ${ }^{6}$

As a result of XYZ's ANDA filing, litigation ensues. ABC files suit against XYZ alleging Drug 70 will infringe its patent covering Drug 23. Realizing that it is in neither company's

2 A patent grants the patentee monopolistic control in a given market. Times-Picayune Pub. Co. v. United States, 345 U.S. 594, 608 (1953). However, control granted by a patent is limited to "the literal scope of the patent claims." Dawson Chem. Co. v. Rohm and Haas Co., 448 U.S. 176, 221 (1980). Therefore, as long as the patentee is within the scope of the patent, they can legally charge a monopolistic price.

3 See discussion infra Section II.C.

4 See discussion infra Section II.C.

5 See 21 U.S.C. $\$ 355(j)(2)(A)$ (vii)(IV) (2015) (Paragraph IV route).

621 U.S.C. $\S 355(\mathrm{j})(2)(\mathrm{A})(\mathrm{vii})(2015)$. 
best interest to be involved in a prolonged legal battle, ABC and XYZ amicably settle before trial begins. The relevant terms of the settlement agreement are as follows:

1. $\mathrm{ABC}$ voluntarily agrees to dismiss the patent infringement suit against XYZ.

2. ABC shall pay XYZ the sum of $\$ 10,000,000.00$ per year for the remaining term of the patent ${ }^{7}$ on Drug 23 .

3. As consideration, $\mathrm{XYZ}$ will refrain from bringing to market Drug 70 until the patent on Drug 23 has expired.

4. XYZ will provide marketing services in regards to ABC's Drug 23. Said marketing services will be comprised of promoting ABC's Drug 23 to physicians.

This type of settlement agreement is known as a reverse payment settlement. The name derives from a defendant in a patent infringement suit receiving something of value, as compared to a normal lawsuit where the plaintiff would receive something of value. In the example above, $A B C$ brought the infringement suit against XYZ, but in the end, $\mathrm{XYZ}$ was the one who received a monetary payment.

\section{A. The Issue}

A large contributing factor to the growing cost of health care in the United States involves the rising cost of prescription drugs. ${ }^{8}$ Critics argue that reverse payment settlements increase the cost of drugs by delaying generic drug entry into the market. 9 Also, some have criticized reverse payment settlements as anticompetitive. ${ }^{10}$ On the other hand, it can be argued that reverse payment settlements are necessary to protect patents which provide

\footnotetext{
7 See infra note 35.

8 See U.S. Census Bureau, Statistical AbStract of the United States: NATional Health Expenditures (2012) (showing total national health care expenditures increased from $\$ 1,286,800,000,000$ in 1999 to $\$ 2,486,300,000,000$ in 2009) [hereinafter 2012 Census].

9 Pay-for-Delay: How Drug Company Pay-Offs Cost Consumers Billions, FED. TRADE COMMISSION (2010), http://www.ftc.gov/ sites/default/files/documents/reports/pay-delay-how-drug-company-payoffs-cost-consumers-billions-federal-trade-commission-staffstudy/100112payfordelayrpt.pdf [hereinafter Pay-for-Delay].

$10 \quad I d$.
} 
incentives $^{11}$ to drug manufacturers to take the risks associated with developing new drugs. ${ }^{12}$ In recent years, the Federal Trade Commission ("FTC") has brought numerous lawsuits in an attempt to have a court hold reverse payment settlements illegal due to their anticompetitive effect. 13

In late 2012, the Supreme Court granted certiorari in order to resolve a circuit split regarding the proper analysis for determining whether a reverse payment settlement is anticompetitive. ${ }^{14}$ The current issue arises as the Court took a middle ground by holding that the rule of reason, ${ }^{15} \mathrm{a}$ standard borrowed from antitrust law, was applicable to reverse payment settlements. In addition, Congressional action ${ }^{16}$ on the horizon potentially conflicts with the Court's opinion. Given that Actavis was handed down June 17, 2013 , its impact is still not fully realized. However, as will be demonstrated in this Note, although the Court has provided little guidance for drug manufacturers, district courts, and the FTC, the rule of reason is a sound choice as it resonates with fundamental and important rationales behind patent law and the Hatch-Waxman Act.

\footnotetext{
11 See Rebecca S. Eisenberg, Patents and the Progress of Science: Exclusive Rights and Experimental Use, 56 U. CHI. L. REV. 1017, 102437 (1989) (discussing theories of justification for monopolies created by patents).

12 Matthew Herper, The Truly Staggering Cost of Inventing New Drugs, ForBES (Feb. 10, 2012, 7:41 AM), http://www.forbes.com/ sites/matthewherper/2012/02/10/the-truly-staggering-cost-of-inventingnew-drugs/. The author notes the cost of research and development, while it varies manufacturer to manufacture, is astronomical. In 2011, on average, AstraZeneca spent $\$ 11.79$ billion, Roche spent $\$ 7.8$ billion, Pfizer spent $\$ 7.72$ billion, and Eli Lilly spent $\$ 4.57$ billion on research and development per drug.

${ }^{13}$ E.g., FTC v. Watson Pharms., Inc., 677 F.3d 1298 (11th Cir. 2012), rev'd sub nom. FTC v. Actavis, Inc., 133 S. Ct. 2223 (2013); ScheringPlough Corp. v. F.T.C., 402 F.3d 1056 (11 th Cir. 2005).

14 Watson Pharms., 677 F.3d 1298, cert. granted, 81 U.S.L.W. 3216 (U.S. Dec. 7, 2012) (No. 12-416).

15 Actavis, 133 S. Ct. at 2237.

16 See Preserve Access to Affordable Generics Act, S. 214, 113th Cong. (2013) (introduced to the Senate on Feb. 4, 2013 and held hearings on July 23, 2013) (establishing a presumption that reverse payment settlements are anticompetitive).
} 


\section{B. Roadmap}

The Court's application of rule of reason analysis was correct and should not be changed by Congress. ${ }^{17}$ The Court's opinion did not prohibit reverse payment settlements per se and in doing so the Court outlined a brief framework for analyzing reverse payment settlements under the rule of reason. This Note addresses the impact of using the rule of reason, what courts will look at, under Actavis, to determine if a reverse payment settlement is pro-competitive, and why the rule of reason was the correct choice for analysis. In order to facilitate a better understanding of reverse payment settlements and recent common law, Section II begins by providing background information about the Hatch-Waxman Act and its application to reverse payment settlements. Additionally, Section II provides information on the existing state of common law pre-Actavis, a brief overview of the rule of reason, and an overview of recent Congressional action. Section III discusses how Actavis will benefit consumers and may cause a slight burden for manufactures. Next, Section III provides a solution for crafting a pro-competitive reverse payment settlement under Actavis. Finally, Section IV discusses a policy recommendation concerning potential Congressional action in regards to reverse payment settlements.

\section{BACKGROUND INFORMATION}

\section{A. Pre-Hatch-Waxman Act}

On June 25, 1938 the Federal Food, Drug, and Cosmetics Act ("FDCA") was signed into law. 18 The FDCA, for the first

17 Contra Brianna Ford, Using Reverse Payment Agreements as an Effective Way to Maintain a Patent Monopoly in the Pharmaceutical Industry, 21 AM. U. J. GENDER SOC. POL'Y \& L. 919, 949 (2013) (arguing for Congress to ban reverse payment settlements).

18 Federal Food, Drug, and Cosmetics Act, Pub. L. No. 75-717, 52 Stat. 1040 (1938) (codified as amended at 21 U.S.C. $\S \S 301-399 f(2015)$ ). 
time, empowered the FDA to review the safety of new drugs. ${ }^{19}$

Before 1962, drugs were only approved for safety without any form of an efficacy requirement. ${ }^{20}$ This would mean that in the earlier example, Drug 23 developed by ABC before 1962, would be approvable without proof of improving a consumer's memory or other intellectual abilities. In 1962, an amendment to FDCA added "a proofof-efficacy requirement [for] new drug approval[s]."21 Subsequently, after 1962, a manufacturer was required to "demonstrate not only the safety of the drug, but that it was effective for its intended use." 22

After 1962, generic drugs generally entered the market through an abbreviated approval process ${ }^{23}$ or through "paper"24 new drug applications. ${ }^{25}$ However, neither the abbreviated approval process nor the "paper" new drug application had a large effect on generic drugs entering the market. The abbreviated approval process had a minimal effect, because it only applied to drugs approved prior to 1962.26 Also, the paper-NDA had little effect because of the lack of publically available information on safety and

19 Elizabeth Stotland Weiswasser \& Scott D. Danzis, The HatchWaxman Act: History, Structure, and Legacy, 71 ANTITRUST L.J. 585, 587 (2003).

20 Gerald J. Mossinghoff, Overview of the Hatch-Waxman Act and its Impact on the Drug Development Process, 54 FoOD \& DRUG L.J. 187, 187 (1999).

21 Id. (discussing the Thalidomide problem in infants led to adding a proof-of-efficacy requirement); see also Russell Mokhiber, The Tragic Children of Thalidomide, 8 MULTINATIONAL MONiTOR 4, 4 (1987) (discussing how pregnant mothers in the 1950s and early 1960s took the drug Thalidomide which caused deformities in babies).

22 Weiswasser \& Danzis, supra note 19, at 588.

23 Id. (discussing how this process only applied to drugs which were approved prior to 1962 and reviewed through the Drug Efficacy Study Implementation).

24 See Mossinghoff, supra note 20 (discussing how the term paper arose because only published scientific or medical literature was used to approve the NDA).

25 Weiswasser \& Danzis, supra note 19, at 589 (explaining how drugs were approved based on publically available data declaring the drug's safety and effectiveness).

26 Id. 
effectiveness for drugs. ${ }^{27}$ This resulted in congressional testimony in 1984 stating "there were 150 drugs that were off-patent, but for which there were no generics because generic companies simply would not spend the time and money doing the clinical trial[s] to get to market, and that there were only fifteen 'paper NDAs,' for post-1962 generics." 28

\section{B. The Hatch-Waxman Act: A Compromise for Pioneer and Generic Manufacturers}

The Drug Price Competition and Patent Term Restoration Act of 1984, commonly known as the HatchWaxman Act, was enacted to revise the procedures for filing a NDA under the FDCA. ${ }^{29}$ The Hatch-Waxman Act attempts to "strike a balance between two competing policy interests: (1) inducing pioneering research and development of new drugs and (2) enabling competitors to bring low-cost, generic copies of those drugs to market." 30 Furthermore, in bringing low-cost drugs to the market, it will allow access to certain drugs for consumers who might not otherwise be able to obtain them.

Public policy support for generic drugs often conflicts with patent law's justifications for granting monopolistic power to the patentee. ${ }^{31}$ In order to induce pioneer research and development, Congress desired for pioneer manufacturers to receive a patent term extension. ${ }^{32}$ As the House reported in 1984, pharmaceutical manufacturers

\footnotetext{
27 Id.

28 Mossinghoff, supra note 20 (citing H.R. REP. No. 98-857, pt. 1 (1984).

29 Drug Price Competition and Patent Term Restoration Act of 1984, Pub. L. No. 98-417, 98 Stat. 1585 (1984).

30 Caraco Pharm. Labs., Ltd. v. Forest Labs., Inc. 527 F.3d 1278, 1282 (Fed. Cir. 2008) (quoting Andrx Pharms., Inc. v. Biovail Corp., 276 F.3d 1368, 1371 (Fed. Cir. 2002)).

31 Eisenberg, supra note 11. Generally, public policy in favor of bringing lower cost drugs in a more timely fashion to market is the hallmark behind generic drugs. Id. Meanwhile, the justification for a monopoly created by a patent can be seen as an "incentive to invent," "incentive to disclose," and an incentive to "invest in innovation." Id.

${ }^{32}$ H.R. REP. No. 98-857, at 15 (1984).
} 
testified that "the average effective patent term of drugs has declined" 33 as a result of government review. ${ }^{34}$ Congress attempted to return this lost time through a "restoration of some of the time lost on patent life while the product is awaiting pre-market approval."35 This restored patent life is "equal to the regulatory review period for the approved product which period occurs after the date the patent is issued." 36

This period is subject to a number of limitations, but as a general matter is one-half the length of time between the effective date of the Investigational New Drug application (IND)_an application allowing a drug sponsor to advance from preclinical to clinical trials-and submission of the NDA, plus the length of time between filing and approval of the NDA, up to a total of five years. ${ }^{37}$

Lastly, the term of the patent after the date of approval plus the period of extension will be adjusted so it does not exceed fourteen years from the date of approval. ${ }^{38}$ These adjustments satisfy Congress' intent to return lost time while the drug is being approved.

In order to improve the amount of generic equivalents on the market, the Act "relax[es] the testing requirements imposed on generic manufacturers and allow[s] them to piggyback on data developed by the pioneer [manufacturer]."39 Specifically, the new procedure for an ANDA allows "generic copies of any drugs [to] be approved if the generic is the same as the original drug or so similar

\footnotetext{
${ }^{33}$ Id. at $17-18$

34 Fact Sheet: New Drug Development Process, CaL. Biomedical RES. ASS'N, http://ca-biomed.org/pdf/media-kit/fact-sheets/ cbradrugdevelop.pdf (last visited Sept. 8, 2014). Patent terms are for twenty years beginning on the date the patent is issued. 35 U.S.C. $\$ 154(\mathrm{a})(2)$. Id. However, the effective patent term must be viewed based on the time in which a drug is available for purchase by consumers. Id. On average, it takes "12 years for a drug to travel from the research lab to the [consumer]." Id. Subsequently, on average, a new drug only has an effective patent term of 8 years.

35 H.R. REP. NO. 98-857, at 15 (1984).

$36 \quad 35$ U.S.C. $\S 156(\mathrm{c})(2015)$.

37 Weiswasser \& Danzis, supra note 19, at 591.

3835 U.S.C. $\$ 156(\mathrm{c})(3)$ (2015).

39 Weiswasser \& Danzis, supra note 19, at 590.
} 
that FDA has determined the differences do not require safety and effectiveness testing." 40

\section{The Hatch-Waxman Act and Reverse Payment Settlements}

Reverse payment settlements are "[p]ayments pursuant to the settlement of a patent [infringement] suit [which flow from the patent holder to the alleged infringer] . . . by contrast, "[t]ypically, in patent infringement cases the payment flows from the alleged infringer to the patent holder." 41 In the context of reverse payment settlements, there are four key features of the Hatch-Waxman Act. ${ }^{42}$ First, a drug manufacturer who develops a new prescription drug must file a NDA with the FDA. ${ }^{43}$ After receiving approval, a drug manufacturer will generally file a patent application with the Patent and Trademark Officer. ${ }^{44}$

40 H.R. REP. No. 98-857, at 14-15 (1984) (explaining how the new ANDA process provides for "piggybacking" off of new pioneer drugs that are submitted after 1962).

41 In re Tamoxifen Citrate Antitrust Litig., 466 F.3d 187, 205 (2d Cir. 2005) (quoting David A. Balto, Pharmaceutical Patent Settlements: The Antitrust Risks, 55 FoOD \& DRUG L.J. 321, 335 (2000)), abrogated by F.T.C. v. Actavis, Inc., 133 S. Ct. 2223 (2013).

42 Actavis, 133 S. Ct. at 2227.

4321 U.S.C. $§ 355(\mathrm{~b})(1)$ (2015) (requiring the following for a NDA: safety and effectiveness reports; components of the drug; composition of the drug; "description of methods used in, facilities and controls used for, the manufacture, processing and packing of drug"; samples and articles of components as required by the Secretary; "specimens of the labeling proposed"; "any assessments required under section 355(c)"; and "[t]he applicant shall file with the application the patent number and the expiration date of any patent which claims the drug for which the applicant submitted the application or which claims a method of using such drug and with respect to which a claim of patent infringement could reasonably be asserted if a person not licensed by the owner engaged in the manufacture, use, or sale of the drug").

44 Obtaining a patent is desirable because it can be used to "invoke the State's power to prevent others from utilizing [one's] discovery without [their] consent." United States v. Westinghouse Elec. Corp., 648 F.2d 642, 647 (9th Cir. 1981). In the United States, patents are issued by the United States Patent and Trademark Office. General Information Concerning Patents, USPTO.GOV, http://www.uspto.gov/ patents/resources/general_info_concerning_patents.jsp\#heading-1 (last 
Thereafter, the FDA lists patents from NDAs in the publication "Approved Drug Products with Therapeutic Equivalence Evaluations."45 Frequently, this publication is referred to as "the Orange Book." 46

Second, after the FDA has approved a pioneer drug, a generic manufacturer can file an ANDA. ${ }^{47}$ Using an ANDA allows the generic manufacturer to piggyback off the pioneer manufacturer and avoid duplicate testing. ${ }^{48}$ However, if the pioneer drug includes a new active

updated Oct. 2014). Generally, there are three types: utility patents (the general "all purpose" patent), design patents (article of manufacture), and plant patents (new plant variety). Patents, USPTO.GOV, http://www.uspto.gov/patents/ (last visited Mar. 8, 2014). Obtaining a patent involves many steps, such as: determining patentability, filing strategy, domestic v. international protection and examination. See generally Process for Obtaining a Utility Patent, USPTO.GOV, http://www.uspto.gov/patents/process/index.jsp?utm_source=feedburner \&utm_medium $=$ twitter\&utm_campaign $=$ Feed\%3A+hackernewsyc $+(\mathrm{Hac}$ ker+News+YC) (last visited Mar. 8, 2014). Lastly, the term of a patent begins when the patent is issued and ends "20 years from the date on which the application for the patent was filed," unless "the application contain a specific reference to an earlier filed application ... [then] from the date on which the earliest such application was filed." 35 U.S.C. $\S$ 154(a)(2) (2015).

45 Caraco Pharm. Labs., Ltd. v. Forest Labs., Inc. 527 F.3d 1278, 1282 (Fed. Cir. 2008).

46 Id.; see also Approved Drug Products with Therapeutic Equivalence Evaluations (Orange Book), U.S. Food \& DRUG ADMIN., http://www.fda.gov/Drugs/InformationOnDrugs/ucm129662.htm （last visited Mar. 8, 2014).

4721 U.S.C. $\S 355(\mathrm{j})(2015)$.

48 For example, in 2011, the branded cholesterol-lowering drug Lipitor came off patent and generic versions were available under the name atorvastatin. Daniel J. DeNoon, Lipitor Goes Generic: What It Means for You, WeBMD (Nov. 29, 2011), http://www.webmd.com/cholesterolmanagement/news/20111129/faq-generic-lipitor. In a letter from Keith Webber, Deputy Director for the Office of Pharmaceutical Science, to Ranbaxy Laboratories, generic Lipitor manufacturer, Webber notes how Ranbaxy's ANDA for their atorvastatin tablets are approved as they were found "to be bioequivalent and, therefore, therapeutically equivalent" to Lipitor tablets. Letter from Keith Webber, Deputy Director, Office of Pharmaceutical Science, to Scott D. Tomsky, Senior Manage, Regulatory Affairs (2011) (on file with author), available at http://www.accessdata.fda.gov/drugsatfda_docs/appletter/2011/076477Orig 1s000ltr.pdf. 
ingredient, which has not been previously approved in any other application, an ANDA cannot be filed until "the expiration of four years from the date of the approval." 49

Third, in order to avoid patent infringement, the generic manufacture must provide a certification that the generic drug will not infringe the patent of the pioneer drug. ${ }^{50}$ The generic manufacturer can certify (1) "that such patent information has not been filed;" (2) that such patent has expired;" (3) "the date on which such patent will expire;" or (4) "that such patent is invalid or will not be infringed by the manufacture, use, or sale of the new drug for which the application is submitted." 51 The fourth option, known as the Paragraph IV route, is enticing to generic manufacturers as it will often allow generic manufacturers to bring its product to the market sooner than under the other three routes. In order to provide some protection, under the Paragraph IV route a pioneer manufacturer has 45 days to bring an infringement suit. ${ }^{52}$

Fourth, a generic manufacturer who is first to file an ANDA under the Paragraph IV route is entitled to an exclusivity period of 180 days after the date of the first commercial marketing of the drug. ${ }^{53}$

\section{Alternative Methods to Analyze Reverse Payment Settlements}

Generic manufacturers frequently certify under the Paragraph IV route. In order to counter this certification, the pioneer manufacturer will bring suit against the generic manufacture alleging patent infringement. In the context of this Note, these suits are resolved through a reverse payment settlement instead of litigating the infringement suit in a court of law. While settlements are generally

4921 U.S.C. $\$ 355(\mathrm{j})(5)(\mathrm{F})(\mathrm{ii})(2015)$.

$50 \quad I d . \S 355(\mathrm{j})(2)(\mathrm{A})(\mathrm{vii})$.

$51 \quad I d . \S 355(\mathrm{j})(2)(\mathrm{A})(\mathrm{vii})(\mathrm{I})-(\mathrm{IV})$.

$52 \quad I d . \S 355(\mathrm{j})(5)(\mathrm{B})(\mathrm{iii})$ (stating further that if an infringement suit is brought, the FDA must withhold approval of the generic drug for a period of 30 months).

53 Id. $\S 355(\mathrm{j})(5)(\mathrm{B})(\mathrm{iv})(\mathrm{I})$. 
favored, the FTC has issue with these reverse payment settlements because, in its eyes, they are anticompetitive. ${ }^{54}$

Before Actavis, federal courts were split on whether antitrust or patent law applied to reverse payment settlements under the Hatch-Waxman Act..$^{55}$ However, initially, due to binding and favorable precedent in the Eleventh Circuit, pharmaceutical manufacturers would generally appeal FTC Final Orders in its jurisdiction. ${ }^{56}$ This allowed pharmaceutical manufacturers to prevent another circuit from creating a circuit split, and in turn make the issue appealable to the Supreme Court. ${ }^{57}$ Eventually, a group of wholesalers and retailers brought a suit involving reverse payment settlements in the Third Circuit. ${ }^{58}$ Subsequently, the Third Circuit's decision in In re

54 See Pay-for-Delay, supra note 9 (explaining how reverse payment settlements "have significantly postponed substantial consumer savings from lower generic prices").

55 Compare In re Ciprofloxacin Hydrochloride Antitrust Litig., 544 F.3d 1323, 1336 (Fed. Cir. 2008) (inquiry is whether the agreement exceeded the exclusionary zone of the patent), abrogated by FTC v. Actavis, Inc., 133 S. Ct. 2223 (2013); In re Tamoxifen Citrate Antitrust Litig., 466 F.3d 187, 212-13 (2d Cir. 2006) (immune from antitrust attack as long as settlement does not exceed scope of patent), abrogated by Actavis, 133 S. Ct. 2223; Valley Drug Co. v. Geneva Pharms., Inc., 344 F.3d 1294, 1311 (11th Cir. 2003) (a reverse payment settlement does not demonstrate a settlement is anticompetitive), with In re K-Dur Antitrust Litig., 686 F. 3d 197, 218 (3d Cir. 2012) (presumably an unreasonable restraint on trade), vacated, Actavis, 133 S. Ct. 2223, and In re Cardizem CD Antitrust Litig., 332 F.3d 896, 908 (6th Cir. 2003) (reverse payment delaying 180 day exclusivity period was a horizontal restraint of trade, which are deemed per se illegal restraints on trade); Andrx Pharms., Inc. v. Biovail Corp. Int'l, 256 F.3d 799, 813 (D.C. Cir. 2001) (agreement to maintain the status quo until end of infringement suit "harms consumers by slowing the introduction of lower priced products into the market").

56 See 15 U.S.C. $§ 45$ (c) (2015) ("Any person, partnership, or corporation required by an order of the [FTC] to cease and desist from using any method of competition or act or practice may obtain a review of such order in the court of appeals of the United States, within any circuit where the method of competition or the act or practice in question was used or where such person, partnership, or corporation resides or carries on business ....") (emphasis added).

57 See SuP. CT. R. 10.

58 In re K-Dur, 686 F.3d at 207. 
K-Dur Antitrust Litigation created a circuit split with the Eleventh Circuit's decision in FTC v. Watson Pharmaceuticals.

\section{The Third Circuit: The Quick Look Rule of Reason Test}

The Third Circuit applied a "quick look" rule of reason analysis. ${ }^{59}$ In doing so, the Third Circuit held that reverse payment settlements were "prima facie evidence of an unreasonable restraint of trade . . ."60 This presumption can be "rebutted by showing that the payment (1) was for a purpose other than delayed entry or (2) offers some procompetitive benefit."61 Based on the presumption of anticompetitive harm, the majority, if not all, reverse payment settlements would be struck down and as a result contradict incentives provided by patent law.

\section{The Eleventh Circuit: Scope of Patent Test}

Conversely, the Eleventh Circuit applied a scope of patent test. ${ }^{62}$ The Eleventh Circuit holds that "absent sham litigation or fraud in obtaining the patent, a reverse payment settlement is immune from antitrust attack so long as its anticompetitive effects fall within the scope of the exclusionary potential of the patent." 63 The key is the potential exclusionary power of a patent, not the actual power. For example, a patent issued for a drug has the potential exclusionary power to exclude all similar drugs. However, at the same time, said patent may not have any

\footnotetext{
59 Id. at 218.

$60 \mathrm{Id}$.

61 Id. (stating that a procompetitive benefit may be "a modest cash payment that enables a cash-starved generic manufacture to avoid bankruptcy and begin marketing a generic drug").

62 See also In re Ciprofloxacin Hydrochloride Antitrust Litig., 544 F.3d 1323, 1336 (Fed. Cir. 2008), abrogated by F.T.C. v. Actavis, Inc., 133 S. Ct. 2223 (2013); In re Tamoxifen Citrate Antitrust Litig., 466 F.3d 187, 212-13 (2d Cir. 2006), abrogated by Actavis, 133 S. Ct. 2223.

63 FTC v. Watson Pharms. Inc., 677 F.3d 1298, 1312 (11th Cir. 2012), rev'd sub nom. Actavis, 133 S. Ct. 2223.
} 
actual power if a court invalidates the patent. Consequently, "actual power" takes into account the validity of the patent while "potential exclusionary power" assumes validity. This leads to the conclusion that "a court judgment about a patent's actual exclusionary power, unless that judgment comes before settlement, does not count."64 The general policy rationale behind the scope of patent test is one of favoring settlement.65 The Eleventh Circuit has specifically noted the high stakes nature of patent litigation and that "parties settle to cap the cost of litigation and to avoid the chance of losing."66

\section{E. The Circuit Split and Supreme Court Decision}

\section{In re K-Dur Antitrust Litigation ${ }^{67}$}

Schering-Plough Corporation ("Schering") obtained the '743 patent on September 5, 1989 for its drug K-Dur.68 Thereafter, two generic manufacturers, Upsher and ESI, filed an ANDA, with a Paragraph IV certification alleging that it would not infringe Schering's '743 patent.69 As a result, Schering brought a patent infringement suit.70 Schering settled with both generic manufactures before a trial occurred. ${ }^{71}$ First, Schering's settlement with Upsher provided that: (a) Upsher would refrain from marketing its generic product until September 1, 2001, when it would receive a non-royalty non-exclusive license under the ' 743 patent; (b) Upsher would grant Schering various licenses for products which Upsher developed; and (c) Schering was to

64 Id. at 1308 (quoting Valley Drug Co. v. Geneva Pharms., Inc., 344 F.3d 1294, 1311 (11th Cir. 2003)).

65 See id. at 1313.

66 Id. (comparing a party who is likely to win patent litigation to a person who is likely to win a game of Russian Roulette, but still not willing to take the chance).

67 In re K-Dur Antitrust Litig., 686 F. 3d 197 (3d Cir. 2012), vacated, Actavis, 133 S. Ct. 2223.

68 Id. at 205.

69 Id. at 205-06

$70 \mathrm{Id}$.

71 Id. 
pay Upsher $\$ 60,000,000$ over three years and other amounts based on the sales of the products licensed to Schering. ${ }^{72}$ Second, Schering's settlement with ESI provided that: (a) ESI would receive a royalty-free license under the '743 patent beginning on January 1, 2004; (b) Schering paid ESI $\$ 5,000,000$ up front; and (c) Schering would pay ESI additional compensation based on when ESI's ANDA was approved by the FDA. ${ }^{73}$

The FTC filed a complaint against Schering, Upsher, and ESI alleging the settlements unreasonably restrained commerce. ${ }^{74}$ In addition, forty-four wholesalers and retailers who purchased K-Dur from Schering brought suit and were certified as a class of plaintiffs. 75 The district court adopted the Report and Recommendation of a Special Master which applied the scope of patent test (a reverse payment settlement is valid as long as it falls within the potential exclusionary effect of the patent) and held that the settlements did not exceed the scope of Schering's '743 patent. ${ }^{76}$

On appeal, the Third Circuit rejected the scope of patent test. 77 The court instructed "the District Court to apply a quick look rule of reason analysis based on the economic realities of the reverse payment settlement rather than the labels applied by the settling parties." "78 "[A] generic patent challenger who agrees to delay entry into the market [is] prima facie evidence of an unreasonable restraint of trade, which [can] be rebutted by showing that the payment

72 Id. at 205.

73 Id. at 206.

$74 I d$. at 206-07. However, the FTC's suit is not part of this appeal. After an Administrative Law Judge dismissed the FTC's complaint, the FTC issued a Final Order that the settlements were unreasonable restraints on commerce. Id. at 207; In re Schering-Plough Corp., Final Order, 136 F.T.C. 956, 1052 (2003). Subsequently, Schering appealed the FTC's Final Order to the Eleventh Circuit which reversed under the scope of patent test. Schering-Plough Corp. v. FTC, 402 F.3d 1056, 1058 (11th Cir. 2005).

75 In re K-Dur, 686 F.3d at 208.

$76 \mathrm{Id}$.

77 Id. at 214.

78 Id. at 218. 
(1) was for a purpose other than delayed entry or (2) offers some pro-competitive benefit."79

2. FTC v. Watson Pharmaceuticals Inc. 80

In 2000, the FDA approved an NDA for Solvay Pharmaceuticals ("Solvay") for its drug AndroGel.81 In 2003, under Paragraph IV certification, Watson Pharmaceuticals, Inc. (now Actavis)82 ("Watson") filed an ANDA for a generic version of AndroGel.83 Further, after Watson filed their ANDA, Paddock Laboratories ("Paddock") also filed an ANDA under Paragraph IV certification. ${ }^{84}$ Not filing a separate ANDA, Par Pharmaceutical ("Par") joined Paddock on the patent litigation in exchange for potential profit from Paddock's generic drug. ${ }^{85}$

As a result of Paragraph IV certification filed by Watson and Paddock, Solvay filed suit for patent infringement within the appropriate forty-five day window. ${ }^{86}$ Litigation ensued until 2006 when all parties settled and entered into the following reverse payment settlement agreements. ${ }^{87}$ First, Solvay's settlement with Watson provided the following: (a) Watson would not bring its generic to market until August 31, 2015, sixty-five months before Solvay's patent expired; (b) Watson would promote AndroGel to urologists; and (c) Solvay would share with Watson an estimated profit of $\$ 19-\$ 30$ million annually for nine years. ${ }^{88}$ Second, Solvay's settlement with Paddock and Par

79 Id

80 FTC v. Watson Pharms. Inc., 677 F.3d 1298 (11th Cir. 2012), rev'd sub nom. F.T.C. v. Actavis, Inc., 133 S. Ct. 2223 (2013).

81 Id. at 1304.

82 Press Release, Actavis, Inc., Watson Announces New Name-Actavis--for Global Operations (Oct. 31, 2012) (on file with author), available at http://phx.corporate-ir.net/phoenix.zhtml?c=65778\&p=irolnewsArticle\&ID=1752588\&highlight=.

83 Watson Pharms., 677 F.3d at 1304.

84 Id.

85 Id.

86 Id.

87 Id. at 1304-05.

88 Id. at 1305 . 
provided for: (a) Paddock/Par would not bring its generic to market until August 31, 2015; (b) Par would promote AndroGel to primary care doctors; (c) Par was to serve as a backup manufacturer; and (d) Paddock/Par would receive $\$ 10$ million per year for six years and $\$ 2$ million per year for the backup manufacturer deal. 89

After reporting the settlement, the FTC filed an antitrust lawsuit against the four companies.90 While Solvay, Watson, Paddock, and Par contended the payments of compensation were for services provided by the generic manufacturers, the FTC alleged that the agreements were just to keep generic AndroGel off the market.91 Applying the scope of patent test, the district court dismissed the FTC's complaint because it did not allege that the settlement exceeded the scope of Solvay's patent. ${ }^{92}$

On appeal, the Eleventh Circuit affirmed. ${ }^{93}$ In doing so, the Eleven Circuit reaffirmed its holding in Valley Drug that "reverse payment settlements are immune from antitrust liability if the anticompetitive effects of their settlement fall "within the scope of the exclusionary potential of the patent."'94

3. FTC v. Actavis, Inc. ${ }^{95}$

After FTC v. Watson Pharmaceuticals Inc. was decided, the Supreme Court of the United States granted certiorari due to the circuit split between the Third and Eleventh Circuit. The Court rejected the Eleventh Circuit's application of the scope of patent test. ${ }^{96}$ In doing so, the Court held that the FTC should have the opportunity to prove its antitrust claim under the rule of reason. ${ }^{97}$

\footnotetext{
89 Id.

90 Id.

$91 \mathrm{Id}$.

92 Id. at 1306.

93 Id. at 1315.

94 Id. at 1309 (quoting Valley Drug Co. v. Geneva Pharms., Inc., 344 F.3d 1294, 1311 (11th Cir. 2003)).

95 FTC v. Actavis, Inc., 133 S. Ct. 2223 (2013).

96 Id. at 2231.

97 Id. at 2234 .
} 
The Court set out a list of five considerations for lower courts to look at when analyzing a reverse payment settlement. First, "the specific restraint at issue has the potential for genuine adverse effects on competition."98 Second, "these anticompetitive consequences will at least sometimes prove unjustified." 99 Third, "where a reverse payment threatens to work unjustified anticompetitive harm, the patentee likely possesses the power to bring that harm about in practice."100 Fourth, "an antitrust action is likely to prove more feasible administratively than the Eleventh Circuit believed."101 Fifth, "the fact that a large, unjustified reverse payment risks antitrust liability does not prevent litigating parties from settling their lawsuit."102

Further, the Court rejected the FTC's argument and Third Circuit's application of a quick look approach. ${ }^{103}$ The Court reasoned that reverse payment settlements are complex and may not be understood by "an observer with . . . [a] rudimentary understanding of economics"104 because "a reverse payment bringing about anticompetitive effects [(a)] depends upon its size, [(b)] its scale in relation to the payor's anticipated future litigation costs, [(c)] its independence from other services for which it might represent payment, and [(d)] the lack of any other convincing justification." 105

In dissent, Chief Justice Roberts, along with Justices Scalia and Thomas, argued that the scope of patent analysis should govern. ${ }^{106}$ The dissent recognized the long-lived principle that a patent is an exception to antitrust law and grants monopolistic powers to the holder. ${ }^{107}$ Moreover, the dissent argued that it has been "long recognized that a patent holder is entitled to license a competitor to sell its product on the condition that the competitor charge a

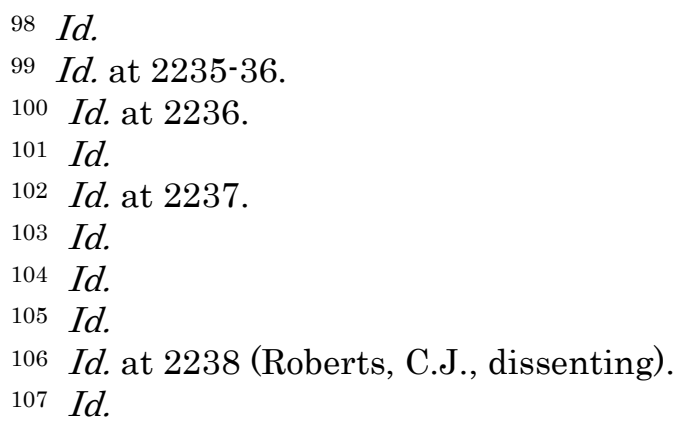


certain, fixed price" and there is no violation of antitrust law "for a competitor to refrain from challenging a patent."108 The dissent went as far as saying that the majorities' approach will ironically "discourage generics from challenging pharmaceutical patents" because of the cost, time, and uncertainty of patent litigation. ${ }^{109}$ Subsequently, the dissent held there can be no violation of antitrust laws when the patent holder is acting within the scope of their patent. 110

\section{F. What is the Rule of Reason?}

Section 1 of the Sherman Act states: "[e]very contract, combination in the form of trust or otherwise, or conspiracy, in restraint of trade or commerce among the several States, or with foreign nations, is declared to be illegal."111 In determining whether there is a restraint on trade in violation of section 1 , courts apply the rule of reason. ${ }^{112}$ What is more, the Supreme Court has interpreted this statute as only prohibiting unreasonable restraints of trade.113 "Under this rule, the factfinder weighs all of the circumstances of a case in deciding whether a restrictive practice should be prohibited as imposing an unreasonable restraint on competition." 114 This inquiry is generally viewed by courts in terms of shifting the burden of proof. 115 First, "the plaintiff carries the burden of showing that an agreement or contract has an anticompetitive effect on a given market within a geographic area."116 Second, "[i]f the

108 Id. at 2239.

109 Id. at 2247.

110 Id. at 2239.

11115 U.S.C. $\S 1$ (2015).

112 Leegin Creative Leather Prods., Inc. v. PSKS, Inc., 551 U.S. 877, 885 (2007).

113 Nat'l Collegiate Athletic Ass'n v. Bd. of Regents of Univ. of Okla., 468 U.S. 85, 98 (1984).

114 Leegin Creative Leather Products, 551 U.S. at 885 (quoting Cont'l T.V., Inc. v. GTE Sylvania Inc., 433 U.S. 36, 49 (1977)).

115 William Holmes \& Melissa Mangiaracina, ANTitrsut LaW HANDBOOK $\S 2: 10$ (2013).

116 Agnew v. Nat'l Collegiate Athletic Ass'n, 683 F.3d 328, 335 (7th Cir. 2012) (citing Reifert v. S. Cent. Wis. MLS Corp., 450 F.3d 312, 321 
plaintiff meets his burden, the defendant can show that the restraint in question actually has a procompetitive effect on balance."117 Third, "the plaintiff can dispute [the defendant's] claim or show that the restraint in question is not reasonably necessary to achieve the procompetitive objective."118 Lastly, some courts recognize that when there are restraints and procompetitive effects, a court must balance the effects. ${ }^{119}$ However, one author argues that balancing is a myth because "[m]ost cases are resolved based on the weight of the evidence and the presence or absence of evidence of competitive effects or evident and substantial efficiencies." 120

\section{G. Congress Addresses Reverse Payment Settlements}

In 2013, Senator Amy Klobuchar introduced the Preserve Access to Affordable Generics Act ("PAAGA").121 The intent of PAAGA is "[t]o prohibit brand name drug companies from compensating generic drug companies to delay the entry of a generic drug into the market." 122 Furthermore, PAAGA includes a strong presumption that a reverse payment settlement is anticompetitive when the generic manufacturer "receives anything of value" or when the generic manufacturer "agrees to limit or forego

(7th Cir. 2006)). See also Major League Baseball Props., Inc. v. Salvino, Inc. 542 F.3d 290, 317 (2d Cir. 2008); Law v. Nat'l Collegiate Athletic Ass'n, 134 F.3d 1010, 1019 (10th Cir. 1998).

117 Agnew, 683 F.3d at 335-36. See also Major League Baseball Props., 542 F.3d at 317; Law, 134 F.3d at 1019.

118 Agnew, 683 F.3d at 336. See also Major League Baseball Props., 542 F.3d at 317; Law, 134 F.3d at 1019.

119 Stop \& Shop Supermarket Co. v. Blue Cross \& Blue Shield of R.I., 373 F.3d 57, 61 (1st Cir. 2004); America Ad Mgmt., Inc. v. GTE Corp., 92 F.3d 781, 789 (9th Cir. 1996).

120 Andrew I. Gavil, Moving Beyond Caricature and Characterization: The Modern Rule of Reason in Practice, 85 S. CAL. L. REV. 733, 761 (2012). (2013).

121 Preserve Access to Affordable Generics Act, S. 214, 113th Cong.

122 Id. 
research, development, manufacturing, marketing, or sales of the [generic] product for any period of time."123

\section{ANALYSIS: THE RESIDUAL EFFECT OF ACTAVIS AND IMPORTANCE OF CRAFTING PRO-COMPETITIVE SETTLEMENTS}

\section{A. Impact of Using Rule of Reason Analysis}

The rule of reason appropriately strikes a balance between and supports the policy rationale behind the Hatch-Waxman Act and patent law. First, rule of reason analysis directly supports one of the intentions behind the Hatch-Waxman Act: having more generic drugs available for consumers. ${ }^{124}$ Second, patent law protection will still be available for pioneer manufacturers, thus, supporting patent law and another rationale behind the HatchWaxman Act: developing new drugs. ${ }^{125}$ Finally, by applying rule of reason analysis to reverse payment settlements, consumers and manufactures are likely to be affected differently, with the former benefiting and the latter burdening.

\section{Effect of Antitrust Laws: How Consumers Benefit}

A 2010 analysis by the FTC found that reverse payment settlements cost consumers $\$ 3.5$ billion annually. ${ }^{126}$ Meanwhile, the goal of antitrust law is to benefit consumers by promoting competition in the marketplace. ${ }^{127}$ By providing greater competition (supply), more suppliers will be forced to fight over a finite number of consumers which can result in the supplier lowering costs or developing a superior product in order to attract consumers. Therefore, by applying antitrust analysis to reverse payment settlements, consumers are likely to benefit from more

123 Id. at $\S 28(\mathrm{a})(2)$.

124 Caraco Pharm. Labs., Ltd. v. Forest Labs., Inc. 527 F.3d 1278, 1282 (Fed. Cir. 2008).

125 Id.

126 Pay-for-Delay, supra note 9.

12758 C.J.S Monopolies $§ 7$ (2014). 
drugs being introduced into the market, an effect supported by the Hatch-Waxman Act.

First, applying the rule of reason will increase market competition by forcing generic companies to enter the market sooner. ${ }^{128}$ Many, if not all, reverse payment settlements, as part of the agreement, require generic manufactures to delay marketing of its drug. ${ }^{129}$ As a result of Actavis, reverse payment settlement will not be able to focus on delaying a generic drug as consideration for a monetary payment by the pioneer manufacturer. In Actavis, the Court made it clear that most delays will not be tolerated. 130 By not including delays, more generic drugs will enter the market in a quicker time frame. This shows how the rule of reason supports the intention behind the Hatch-Waxman Act to have more generic drugs on the market. 131 Therefore, more generic drugs will be able to enter the markets sooner, which will result in more competition between drug manufacturers.

On the other hand, as Chief Justice Roberts argued in Actavis, generic manufacturers may challenge pioneer manufacturer's patents less often. ${ }^{132}$ Generally, patent litigation is expensive and time consuming. Generic manufacturers will need to weigh the costs and benefits of bringing a lawsuit, and there may be times where a generic manufacturer chooses not to bring lawsuit when it would have pre-Actavis. Moreover, generic manufacturers may

128 Angela Maas, Supreme Court Punts on Pay-for-Delay, Prompting Disagreement Over Impact, AIS HEALTH (June 21, 2013), http://aishealth.com/archive/ndbn062113-02.

129 Ark. Carpenters Health and Welfare Fund v. Bayer AG, 604 F.3d 98, 102 (2d Cir. 2010) (delay until patent expired); Schering-Plough Corp. v. F.T.C. 402 F.3d 1056, 1060 (11th Cir. 2005) (delay until three years before patent expired); Valley Drug Co. v. Geneva Pharms., Inc. 344 F.3d 1294, 1300 (11th Cir. 2003) (delay until another generic entered market or patent expired); La. Wholesale Drug Co., Inc. v. Shire LLC, 929 F.Supp.2d 256, 258 (S.D.N.Y. 2013) (three year delay).

130 FTC v. Actavis, Inc. 133 S. Ct. 2223, 2234 (2013).

131 See id. (citing 148 Cong. Rec. 14437 (2002) (remarks of Sen. Hatch) ("It was and is very clear that the [Hatch-Waxman Act] was not designed to allow deals between brand and generic companies to delay competition.")).

132 Id. at 2247 (Roberts, C.J., dissenting). 
not want to spend money and invest the necessary time when there is a level of uncertainty surrounding the validity of a patent. As a result, Actavis may not effectuate the intent of Hatch-Waxman to increase the amount of generic drugs in a market.

Second, consumers will receive lower-cost drugs marketed in a more timely fashion. ${ }^{133}$ Part of the growing cost of healthcare involves the rising cost of prescription drugs. From 2005 until 2009, the cost of prescription drugs has risen from $\$ 201.7$ billion to $\$ 249.9$ billion per year. ${ }^{134}$ The FDA has reported, on average, generic drugs cost 80$85 \%$ less than brand name drugs. ${ }^{135}$ It is estimated that generic drugs saved consumers $\$ 700$ billion from 1999 until 2008.136 Further, some estimations state that reverse payment settlements cost consumers approximately $\$ 3.5$ billion per year. ${ }^{137}$ Under Actavis, generic manufacturers will be able to introduce more generic drugs into the market in a more consumer friendly time. Generic drugs will be marketed sooner as a result of Actavis because settlement agreements between pioneer and generic manufacturers will likely not include delays or will include delays that are substantially less than pre-Actavis settlements. More generic drugs in the market will translate into more generic drugs being available for consumers at a lower cost, a result of basic economic principles of supply and demand. Consequently, the rule of reason furthers the intent of the Hatch-Waxman Act to lower the cost of drugs for consumer.

133 Aaron Kesselheim \& Nathan Shiu, FTC v. Actavis: The Supreme Court Issues a Reversal on Reverse Payments, HEALTH AFFAIRs BLOG (June 21, 2013), http://healthaffairs.org/blog/2013/06/21/ftc- ${ }^{-}$-actavisthe-supreme-court-issues-a-reversal-on-reverse-payments/.

1342012 Census, supra note 8.

135 Facts About Generic Drugs, U.S. Food \& Drug AdMInistration, http://www.fda.gov/drugs/resourcesforyou/consumers/buyingusingmedici nesafely/understandinggenericdrugs/ucm167991.htm (last visited Sept. 17, 2014).

136 Scott Hemphill \& Bhaven N. Sampat, When Do Generics Challenge Drug Patents?, 8 J. EMPIRICAL LEGAL STUD. 613, 614 (2011).

137 FTC v. Watson Pharms., Inc. 677 F.3d 1298, 1302 (11th Cir. 2012). 
Alternatively, it is a possibility that pioneer manufacturers may pass on any lost profits to consumers. Pioneer manufacturers whose patent term is undercut are at risk of losing a substantial amount of revenue. In order to counter this, pioneer manufacturers may charge a higher price during its initial selling period (when the patent still protects its ability to charge monopolistic prices). Regardless, consumers may benefit because the costs passed on may not rise to the billions of extra dollars consumers spend on branded drugs due to monopolistic prices. ${ }^{138}$

Third, consumers may improve their health outcomes as a result of pioneer manufacturers developing more new active ingredient drugs. As a result of Actavis, pioneer drug manufacturers may allocate more resources into developing new active ingredients as opposed to updating formulas of old products. ${ }^{139}$ As one empirical study, analyzing what type of drug patents get challenged most frequently under the Paragraph IV route, suggests, generic companies more often challenge pioneer drugs using a new formulation as compared to pioneer drugs containing a new active ingredient. ${ }^{140}$ By focusing on new active ingredients, there is a lower risk of patent litigation because a generic company is less likely to challenge the patent's validity. While new active ingredient drugs may be less likely to be challenged, it would be unwise to expect a huge shift in development of new active ingredient drugs as they are

138 See Pay-for-Delay, supra note 9 (explaining that a brand name drug cost $\$ 300 /$ month while the generic equivalent costs $\$ 30 /$ month).

139 Kesselheim \& Shiu, supra note 133.

140 Hemphill \& Sampat, supra note 136, at 643. Analyzing Paragraph IV challenges under the Hatch-Waxman Act, as a sample size, the researchers looked at drugs that were first eligible for challenge in 2000-2008. Id. In their findings, they found a strong association between patent portfolios and generic challenges. Id. Specifically, non-active ingredient patents are challenged more frequently. $I d$. Further, patent portfolios with low-quality patents, extra nominal patents and late filed patents are much more likely to draw a Paragraph IV challenge. Id. The authors rejected the hypothesis that the composition of a drug's patent portfolio is not correlated to Paragraph IV challenges. Id. Subsequently, as opposed to the conventional wisdom that challenges are only about sales, patent portfolio characteristics may have a significant effect. $I d$. 
extremely costly and still subject to patent challenges. With all that is considered, pioneer drug manufacturers who input more resources into new active ingredients will likely have an increased chance, albeit a small increase, of avoiding patent litigation while also providing socially valuable research and development. ${ }^{141}$ Accordingly, the policy interests of the Hatch-Waxman Act and patent law are supported as new research will be completed, resulting in new drug development.

However, developing new active ingredient drugs may not be a realistic business model for all pioneer manufactures. New drug development takes on average ten to fifteen years and costs, on average, over $\$ 1.3$ billion. ${ }^{142}$ Also, not all new drugs are approved by the FDA nor are all expenditures for research and development recouped. ${ }^{143}$ This disincentive for developing new drugs can be alleviated, in part, through patents. "Strong protection of intellectual property rights, and the accompanying rewards, provides an incentive for pharmaceutical companies to make such a large, high-risk investment." 144 One solution to the disincentive created by cost may be for Congress to provide greater incentives for developing new active ingredient drugs by providing them with a longer patent term or make it harder for generic manufacturers to challenge patents based on new active ingredients.

141 See id. at 644 (suggesting that Paragraph IV challenges target drugs with weak late-expiring patents and because weak late-expiring patents are assumed to be less related to socially valuable research and development, challenges may be an important means to curtail patents that have high social costs which stem from sustaining high prices for consumers).

142 Bret Dickey et al., An Economic Assessment of Patent Settlements in the Pharmaceutical Industry, 19 Annals Health L. 367, 369 (2010).

143 Id.

144 Id. 


\section{Effect of Antitrust Laws: Different Affect on Drug Manufacturers}

Since the advent of reverse payment settlements, courts analyzing these settlements under the scope of patent test provided manufacturers with "a safety net." The scope of patent test provided manufacturers with an "almost unrebuttable presumption of patent validity."145 Any act of Congress creating a presumption against reverse payment settlements ${ }^{146}$ will create unwarranted burdens for drug manufacturers to a much stronger degree than the rule of reason. In retreating from a presumption of patent validity under the scope of patent test, drug manufacturers, under the rule of reason analysis, will be burdened, but in a manageable way. Subsequently, burdens placed on drug manufacturers will adversely affect the intentions behind the Hatch-Waxman Act and patent law to stimulate innovative research and development.

First, due to ambiguity created by Actavis, parties in a patent infringement suit will be less likely to settle and more likely to litigate. Further, any presumption against reverse payment settlements enacted by Congress will further deter manufacturers from considering settlement. Fewer settlements equate to patent infringement suits becoming more expensive for both pioneer and generic manufacturers. Increases in litigation costs can arise out of "(1) direct litigation costs, (2) indirect costs, such as requiring the attention of company executives, distracting them from the operation of the business, and (3) costs due to the uncertainty of litigation outcomes." 147 Also, applying the rule of reason analysis will lead to more expansive discovery ${ }^{148}$ which will lengthen lawsuit duration and

145 In re K-Dur Antitrust Litig., 686 F.3d 197, 214 (3d Cir. 2012).

146 See Preserve Access to Affordable Generics Act, S. 214, 113th Cong. § 28(a)(2) (2013) (establishing a presumption that reverse payment settlements are anticompetitive).

147 Dickey, supra note 142, at 375.

148 Cal. Dental Ass'n v. FTC, 526 U.S. 756, 759 (1999) (explaining how rule of reason analysis "demands a more thorough enquiry" than a "quick-look" analysis). 
thereby increase the cost of litigation. ${ }^{149}$ Although, while the Court stated that it was not establishing a quick-look analysis, ${ }^{150}$ the Court's emphasis on the "size of payment" 151 implies there is an element of quick-look analysis which the Court has subtly approved. As a result, it is unlikely that all litigation will be lengthy. As the Court suggests, it is not always necessary to litigate patent validity in order to determine if the settlement is anticompetitive. ${ }^{152}$

Increased cost of litigation may also result in generic manufacturers challenging fewer patents. Generic manufacturers may be reluctant to challenge a patent as generic manufacturers have historically lost more often than not when patent litigation proceeds to a judgment.153 As Chief Justice Roberts argued in dissent, the majority's opinion may discourage generic manufacturers from certifying under Paragraph IV as "[p]atent litigation is costly, time consuming, and uncertain." 154 As a result, it may only be economically feasible for generic manufacturers to challenge certain patents and not challenge other patents it would have pre-Actavis. Therefore, generic manufactures may choose to only target weak patents, ones that have a high likelihood of invalidity. ${ }^{155}$

149 See Ariz. v. Maricopa Cnty. Med. Soc'y, 457 U.S. 332, 343 (1982)( "The elaborate inquiry into the reasonableness of a challenged business practice entails significant costs."); Kenneth R. O'Rourke et al., FTC v. Actavis: Reconciling Conflicts In Rule of Reason, LAW 360 (July 2, 2013, 5:55 PM), http://www.law360.com/articles/453428/ftc- - ${ }^{-}$-actavis ${ }^{-}$ reconciling-conflicts-in-rule-of-reason.

150 FTC v. Actavis, Inc., 133 S. Ct. 2223, 2237 (2013).

151 Id. at 2236-37 (suggesting that a large, unexplainable reverse payment implies a patent is weak and precludes a court from "conduct[ing] a detailed exploration [into] the validity of the patent").

152 Id. at 2236.

153 Bret Dickey \& Jonathan Orszag, The Benefits of Patent Settlements: New Survey Evidence on Factors Affecting Generic Drug Investment, GENERIC PHARM. ASS'N (July 23, 2013), http://www.gphaonline.org/media/cms/Dickey_Orszag_Benefits_of_Pate nt_Settlements_2012-07-21_FINAL.pdf (finding when patent litigation goes to a judgment generic manufacturers loose two out of three times).

154 Actavis, 133 S. Ct. at 2247 (Roberts, C.J., dissenting).

155 See Hemphill \& Sampat, supra note 136, at 635-36 (finding a correlation between patent strength and likelihood of a challenge to validity). 
Second, pioneer manufacturers will lose revenue and profits by not being able to delay generic manufacturers from entering the market. This will result from more consumers purchasing the less expensive generic drug. For example, Solvay Pharmaceuticals, the pioneer manufacturer in Actavis, estimated the generic version of AndroGel could decrease the sales of branded AndroGel by $90 \%$ and cut Solvay's profits by $\$ 125$ million per year. ${ }^{156}$ Additionally, in 2013, Pfizer reported that the loss of patent protection in November 2011 on Lipitor and other patents expiring around that time resulted in a reduction in net income by " $\$ 3$ billion to $\$ 4$ billion a year." 157 Contrary to the Hatch-Waxman Act and patent law, which attempt to incentivize pioneer manufacturers to develop new drugs, losing such a large amount of revenue will disincentivize pioneer manufacturers from developing new drugs in the future.

On the other hand, pioneer manufacturers may not suffer any substantial loss of revenue. Generic manufacturers take into account many factors, like most other businesses, before choosing to invest in a product. One report which polled generic manufacturers, and had it rank its most important factors affecting investment decisions, found that ability to settle litigation was more important than items such as number of patents or market size. ${ }^{158}$ This finding shows that in some circumstances, a generic manufacturer may be influenced by a decreased likelihood of ability to settle. As a result, generic manufacturers in the future may not invest in as many products and subsequently, file fewer ANDAs under the Paragraph IV route.

Third, reverse payment settlements may be uncertain and dangerous to enter into, and as a result manufacturers 2012).

156 FTC v. Watson Pharms., Inc. 677 F.3d 1298, 1305 (11th Cir.

157 Pressure from Generic Drugs Shrinks Profit at Pfizer, N.Y. Times (Oct. 29, 2013), http://www.nytimes.com/2013/10/30/business/ pressurefrom-generic-drugs-shrinks-profit-at-pfizer.html?_r=0.

158 Dickey \& Orszag, supra note 153 (finding that ability to settle litigation had an average importance of 2.93/5). 
may risk millions of dollars on the outcome of litigation. 159 This may be seen as a large burden placed on manufacturers because "[m]ost patent litigation is resolved through a settlement between the parties."160 Moreover, this uncertainty and influence on reverse payment settlements will vary as some companies may be more risk averse than others.

The Supreme Court in Actavis chose not to establish a bright line rule and instead laid out five general considerations for lower courts. ${ }^{161}$ In doing so, until precedent is established, there will be uncertainty on whether or not a reverse payment settlement is anticompetitive. Even after the advent of precedent, there will still be uncertainty between the different circuits. This uncertainty will lead manufacturers to avoid settlements and litigate to judgment. In doing so, funds that could be spent on research and development will be funneled into costly litigation. For instance, in the case of a pioneer manufacturer, it will be risking billions of dollars on a district court's interpretation of Actavis. While the rule of reason will place small burdens on manufacturers, any presumption of anticompetitiveness established by Congress will cause more severe burdens on manufacturers.

\section{B. Complying with the Actavis Framework: \\ Crafting Procompetitive Reverse Payment Settlements}

In Actavis, the Court held that "the likelihood of a reverse payment bringing about anticompetitive effects [(a)] depends upon its size, $[(\mathrm{b})]$ its scale in relation to the payor's anticipated future litigation costs, [(c)] its independence from other services for which it might represent payment,

\footnotetext{
159 Jennifer Driscoll-Chippendale \& Bradley Graveline, FTC v. Actavis: What Does It Mean for Reverse-Payment Settlement?, JDSUPRA BUSINESS ADVISOR (June 24, 2013), http://www.jdsupra.com/legalnews/ftc-v-actavis-what-does-it-mean-forre-68321/.

160 Dickey, supra note 142, at 373-74 (citing Carl Shapiro, Antitrust Limits to Patent Settlements, 43 RAND J. OF ECON., 391, 392 (2003)).

161 FTC v. Actavis, Inc., 133 S. Ct. 2223, 2234-37 (2013).
} 
and $[(\mathrm{d})]$ the lack of any other convincing justification." 162 Although, "there is always something of a sliding scale in appraising reasonableness ...."163 Actavis correctly held that the rule of reason is appropriate for analyzing reverse payment settlements. Allowing pioneer manufacturers to create procompetitive reverse payment settlements furthers the intent behind the Hatch-Waxman Act by benefiting both consumers and drug manufacturers. Additionally, the motivation created by patent law to develop new drugs will not be at risk because settlements protect a manufacturer's rights under its patent. Conversely, any act by Congress to create a presumption that reverse payment settlements are anticompetitive ${ }^{164}$ will adversely affect the rationale behind the Hatch-Waxman Act and patent law. The following is an analysis of relevant antitrust factors, the Court's considerations in Actavis, and other relevant considerations which support the rationale behind the Hatch-Waxman Act and patent law.

\section{What Type of Payments Implicate the Actavis Analysis?}

When does Actavis apply? Does it apply to only monetary payments? The Supreme Court has stated "the rule of reason requires the factfinder to decide whether under all the circumstances of the case the restrictive practice imposes an unreasonable restraint on competition."165 A straightforward reading of this statement would lead one to believe Actavis applies in all cases where a reverse payment settlement creates unreasonable restraints on trade. This is supported by antitrust common law which generally focuses on unreasonable restraints caused by the restrict practice. ${ }^{166}$

162 Id. at 2237.

163 Id. (quoting Cal. Dental Ass'n v. FTC, 526 U.S. 756, 780 (1999)).

164 Preserve Access to Affordable Generics Act, S. 214, 113th Cong. (2013).

165 Ariz. v. Maricopa Cnty. Med. Soc'y, 457 U.S. 332, 343 (1982).

166 See Cont'l T.V., Inc. v. GTE Sylvania Inc., 433 U.S. 36, 49 (1977); Bd. of Trade of City of Chi. v. United States, 246 U.S. 231, 238 (1918); 
Although, the language of Actavis does not speak broadly, it speaks narrowly, in reference to monetary payments. As Judge Walls stated: "[b]oth the majority and dissenting opinions reek with the discussion of payment of money."167 Throughout the opinion, the Court continuously discusses reverse payments in terms of a monetary payment, as opposed to a reverse payment for any financial benefit. 168 Therefore, this language implies that Actavis only applies to those reverse payment settlements involving monetary payments.

\section{Market Power}

According to the Supreme Court, the market power possessed by the pioneer manufacturer may indicate anticompetitive harm. ${ }^{169}$ Under rule of reason analysis, "a plaintiff must show that the defendant has market powerthat is, the ability to raise prices significantly without going out of business-without which the defendant could not cause anticompetitive effects on market pricing." 170 Also, a plaintiff may "establish anticompetitive effect indirectly by proving the defendant possessed the requisite market power within a defined market."171 Congress' approach, applying a presumption of anticompetitive harm, ${ }^{172}$ is erroneous as it

Major League Baseball Props., Inc. v. Salvino, Inc. 542 F.3d 290, 316 (2d Cir. 2008).

167 In re Lamictal Direct Purchaser Antitrust Litig., 18 F.Supp.3d 560, 567 (D. N.J. 2014).

168 FTC v. Actavis, Inc., 133 S. Ct. 2223, 2227 (2013) ("Company A, the patentee, to pay B many millions of dollars.") (emphasis added); id. at 2233 ("In reverse payment settlements . . . a party with no claim for damages . . . walks away with money.") (emphasis added); id. at 2235 ("[P]atentees sometimes pay a generic challenger a sum even larger than what the generic would gain in profits.").

169 Id. at 2236.

170 Agnew v. Nat'l Collegiate Athletic Ass'n, 683 F.3d 328, 335 (7th Cir. 2012) (citing Valley Liquors, Inc. v. Renfield Importers, Ltd., 822 F.2d 656, 666 (7th Cir. 1987)).

171 Law v. Nat'l Collegiate Athletic Ass'n, 134 F.3d 1010, 1019 (10th Cir. 1998).

172 Preserve Access to Affordable Generics Act, S. 214, 113th Cong. $\S 28(\mathrm{a})(2)(2013)$. 
presumes the pioneer manufacturer has market power when that may not be accurate in one-hundred percent of cases.

In Actavis, the Court was concerned with a pioneer manufacturer using monopolistic power to receive "higherthan-competitive profits."173 A pioneer manufacturer who is receiving monopolistic profits may use this power to leverage and finance a deal to provide the generic manufacturer with an otherwise unexplainably large settlement payment. Due to the monopolistic power of said manufacturer, a pioneer manufacturer could pay the generic manufacturer an exorbitant amount and recoup those losses in the form of higher prices or by keeping the product at the monopolistic price for more years, which in turn harms consumers. Moreover, this "market power" factor will be product specific. Market power will be less relevant in markets where competition is greater and other alternatives to the pioneer manufacturer's drug exist. Subsequently, in a market with minimal competition, a large reverse payment may look more like an attempt by the pioneer manufacture to keep their monopoly and continue to charge a monopolistic price to consumers.

\section{Relevant Market}

Under the rule of reason, a plaintiff's initial burden is to establish the anticompetitive effect on a given market. ${ }^{174}$ "Antitrust claims often rise or fall on the definition of the relevant market." 175 The Supreme Court has held that the relevant market consists of "commodities reasonably

173 Actavis, 133 S. Ct. at 2236; see also In re Nexium (Esomeprazole) Antitrust Litig., 968 F. Supp. 2d 367, 389 (D. Mass. 2013) (noting that AstraZeneca exercised market power by using its monopolistic position to "charge supracompetitive prices for brand Nexium").

174 Agnew, 683 F.3d at 335 (citing Reifert v. S. Cent. Wis. MLS Corp., 450 F.3d 312, 321 (7th Cir. 2006)); Major League Baseball Props., Inc. v. Salvino, Inc. 542 F.3d 290, 317 (2d Cir. 2008); Law, 134 F.3d at 1019.

175 Se. Mo. Hosp. v. C.R. Bard, Inc., 642 F.3d 608, 613 (8th Cir. 2011) (quoting Bathke v. Casey's Gen. Stores, Inc., 64 F.3d 340, 345 (8th Cir. 2009)). 
interchangeable by consumers for the same purposes . . . "176 For instance, the district court in In re Nexium said the "relevant market [was] comprised of brand and generic Nexium ...." 177

Notwithstanding the fact that generics are intended to be substitutes, an argument could be made that pioneer and generic drugs are in different markets because a consumer, based on personal preference, would not substitute one product for another despite a decrease in price by one of the drugs. ${ }^{178}$ For example, if an inactive ingredient 179 in the generic drug adversely affects consumers to the point that consumers will only purchase the branded drug. However, this would likely require a drug being used by a small number of consumers who all, or at least a large majority, are adversely affected by the same inactive ingredient in the generic drug.

\section{Redeeming Virtues}

In the context of reverse payment settlements, even the FTC has admitted "offsetting or redeeming virtues are sometimes present."180 A defendant under the rule of reason can rebut the plaintiff's initial burden by showing procompetitive effects from the restraint. ${ }^{181}$ Payments may be justified if they are intended to allow the generic manufacturer to develop other (additional) generic drugs for the consumer's benefit. ${ }^{182}$ Moreover, any redeeming virtue

176 United States v. E.I. du Pont de Nemours \& Co., 351 U.S. 377, 395 (1956).

177 In re Nexium, 968 F. Supp. $2 d$ at 389.

178 See E.I. du Pont de Nemours \& Co., 351 U.S. at 400.

179 Generic Drugs: Answers to Common Questions, WeBMD, http://www.webmd.com/healthy-aging/guide/generic-drugs-answers-tocommon-questions (last visited Aug. 27, 2014) (discussing how generic drugs can have different inactive ingredients).

180 FTC v. Actavis, Inc., 133 S. Ct. 2223, 2236 (2013).

181 Agnew v. Nat'l Collegiate Athletic Ass'n, 683 F.3d 328, 335-36 (7th Cir. 2012); Major League Baseball Props., Inc. v. Salvino, Inc. 542 F.3d 290, 317 (2d Cir. 2008); Law v. Nat'l Collegiate Athletic Ass'n, 134 F.3d 1010, 1019 (10th Cir. 1998).

182 Jeff Overley, Big Pharma's Legal Bill to Take Hit From Pay-ForDelay Ruling, LAW 360 (June 17, 2013, 8:08 PM), 
or benefit provided must be more compelling than the policy favoring settlements; ${ }^{183}$ the Court has held that this factor alone is not sufficient to overcome anticompetitive consequences. ${ }^{184}$

For example, based on the example in the introduction, XYZ agrees not to enter into the market for ABC's Drug 23.185 As consideration, ABC provides some form of compensation to $\mathrm{XYZ}$ which in turn lets $\mathrm{XYZ}$ introduce one or more other generic drugs into the market. While the consumers may be hurt by the anticompetitive effect of not allowing XYZ to sell generic Drug 70, the consumers may benefit overall due to other generic drugs XYZ will introduce into the market. ${ }^{186}$

This hypothetical situation would require the drug manufacturers to show there are procompetitive effects caused by not allowing one generic drug to enter the market. As a result, the consumer benefit would outweigh harm through development and production of other generic drugs. Moreover, it would be necessary for the drug manufacturers to show the restraint caused by the reverse payment settlement is reasonably necessary to achieve the procompetitive effect. ${ }^{187}$ Subsequently, in the antitrust

http://www.law360.com/articles/450706/big-pharma-s-legal-bill-to-takehit-from-pay-for-delay-ruling.

183 In re Nexium (Esomeprazole) Antitrust Litig., 968 F. Supp. 2d 367, 410 (D. Mass. 2013) (holding that settlement of patent disputes does not overcome anticompetitive consequences).

184 Actavis, 133 S. Ct. at 2234 (discussing how the Eleventh Circuit's justification based on policy favoring settlements is not determinative).

185 See supra Section I.

186 Contra In re Nexium, 968 F. Supp. 2d at 391 (finding that anticompetitive consequences resulted from pioneer manufacture forgiving contingent liabilities owed to them by generic manufacturers, for infringement of unrelated patents, in exchange for generic manufacturers agreeing that the pioneer manufacturer's patents were valid, being infringed by them, and they would delay the sale of generic Nexium).

187 See Agnew v. Nat'l Collegiate Athletic Ass'n, 683 F.3d 328, 336 (7th Cir. 2012) (plaintiff can rebut defendant assertion of a procompetitive effect by showing it is not reasonably necessary to achieve the objective); see also Major League Baseball Props., Inc. v. 
context, creating an overall benefit for consumers may be seen as a redeeming virtue.

Additionally, a cash payment from a pioneer manufacture to a generic manufacture may be procompetitive depending on the economic situation of the generic manufacturer. As the Third Circuit suggested, "a modest cash payment that enables a cash-starved generic manufacturer to avoid bankruptcy and begin marketing a generic drug might have an overall effect of increasing the amount of competition in the market."188 This example would provide a redeeming virtue that would not otherwise occur absent the reverse payment settlement.

\section{Size of Monetary Payments}

Of main concern for the Court was a pioneer manufacturer offering a large sum of money to a generic manufacturer in order to keep its product out of the market so the pioneer manufacture can maximize revenue at the expense of consumers. 189 For example, a large payment was clearly made when a pioneer manufacturer agreed to pay a generic manufacturer over $\$ 1,000,000,000$ in exchange for the generic manufacturer agreeing that the pioneer manufacturer's patents were valid, being infringed by the generic manufacturer, and having the generic manufacturer delay entry. 190 As one commentator puts it, "the larger the reverse payment, the riskier the settlement from an antitrust perspective."191 Keeping the monetary payment in the settlement consistent with some of the justifications below will go a long way in showing that the reverse payment settlement does not present anticompetitive harm

Salvino, Inc. 542 F.3d 290, 317 (2d Cir. 2008); Law v. Nat'l Collegiate Athletic Ass'n, 134 F.3d 1010, 1019 (10th Cir. 1998).

188 In re K-Dur Antitrust Litig., 686 F. 3d 197, 218 (3d Cir. 2012)

189 Actavis, 133 S. Ct. at 2234.

190 In re Nexium, 968 F. Supp. 2d at 381-82.

191 What Does FTC v. Actavis Inc. Mean for Hatch-Waxman

Litigation?, CROWELL MORING (June 21, 2013), http://www.crowell.com/NewsEvents/AlertsNewsletters/all/What-Does-

FTC-v-Actavis-Inc-Mean-for-Hatch-Waxman-Litigation\#.Um6ZAfmsim5 [hereinafter Crowell Moring Article]. 
and supports the rationale behind the Hatch-Waxman Act and patent law. ${ }^{192}$

One clear justification for reverse payments given by the Court is anticipated future litigation costs saved as a result of the settlement. ${ }^{193}$ This indicates that in a patent infringement suit, pioneer and generic manufacturers should attempt to settle as early as possible. Settling early will ensure a larger cost saved and subsequently, a larger reverse payment will be justified. Also, it may be argued that indirect costs and uncertainty of the litigation's outcome may increase future litigation costs. Lastly, the complexity of the issue and the number of parties involved will also increase future litigation costs.

Additionally, the Court was concerned with payment sizes which seek to "pay a generic challenger a sum even larger than what the generic would gain in profits." 194 Economic projections showing a generic manufacturer earning more revenue by entering the market, as opposed to a settlement, will be persuasive. When the settlement is greater than the generic manufacturer's expected revenue, it suggests the pioneer and generic manufacturer have an ulterior motive to settle. For example, a pioneer and generic manufacturer may earn more revenue by teaming up and charging monopolistic prices to consumers instead of competing against each other. Conversely, a reverse payment settlement not seeking to solely protect the pioneer manufacturer's monopoly will be viewed as pro-competitive.

Payments may be further justified if the generic manufacturer provides a service to the pioneer manufacturer. ${ }^{195}$ Such services may include distribution, 196

192 In re Lamictal Direct Purchaser Antitrust Litig., 18 F.Supp.3d 560, 570 (D. N.J. 2014) (finding that the value to the generic manufacturer "likely exceed[ed] what the parties would have spent litigating the patent dispute, the consideration which the parties exchanged in the settlement is reasonably related to the removal of the uncertainty created by the dispute").

193 Actavis, 133 S. Ct. at 2236.

194 Id. at 2235 (citing C. Scott Hemphill, Paying for Delay: Pharmaceutical Patent Settlements as a Regulatory Design Problem, 81 N.Y. U. L. REV. 1553, 1581 (2006)).

195 Id. at 2236. 
marketing, ${ }^{197}$ consulting, administration, research, quality control, licensing ${ }^{198}$ and any other business arrangement which is reasonable. For example, in Actavis, Actavis, Paddock, and Par provided consideration to Solvay by agreeing to promote Solvay's AndroGel to physicians. ${ }^{199}$ Also, based on the Court's concerns with overpayment, it will be important to determine the fair market value of any services that are provided.

Further, a reverse payment which is more than the expected loss to the pioneer manufacturer, if they lose the litigation and the generic manufacturer enters the market, implies anticompetitiveness and "pay-for-delay." This type of payment suggests the pioneer manufacturer's motive is to keep the generic manufacturer out of the market. For example, using the example from the introduction, if $\mathrm{ABC}$ is expected to lose $\$ 5$ million in revenue when $\mathrm{XYZ}$ enters the market, but enters into a reverse payment for $\$ 6$ million, ABC's likely motivation is to be able to continue to exert its monopolistic power. On the contrary, a payment which is less than the expected loss to the pioneer manufacturer suggests its motive is not to keep the generic manufacturer out of the market.

One way of determining the expected cost to the pioneer manufacturer when losing the patent litigation would be to take the potential lost profits from the generic manufacturer entering the market, mitigated by the litigation odds, and add in any costs saved by settling. ${ }^{200}$ Assume the following:

196 Id.

197 Id.

198 Client Memorandum from Davis Polk \& Wardwell LLP (June 18, 2013) (on file with author), available at http://www.davispolk.com/ download.php?file=sites/default/files/files/Publication/3c1830cd-3c92-

41fc-beff-d7b544d7d7d5/Preview/PublicationAttachment/c59b096e-696f4951-abde-d8c44acadeb6/06.18.13.FTCv.Actavis.pdf.

199 Actavis, 133 S. Ct. at 2229.

200 Peter Todaro et al., Applying the Supreme Court's Decision in Actavis, KING \& SPALDING (July 24, 2013), http://www.kslaw.com/ imageserver/KSPublic/library/publication/ca072413.pdf. 
(1) the [pioneer manufacturer's] future prepatent expiration revenues had a net present value of $\$ 1$ billion; (2) the [pioneer manufacturer] would lose $90 \%$ of its sales upon generic entry; and (3) the [pioneer manufacturer's] probability of litigation success was $60 \%$ making its chance of losing $40 \%$ : then the value of a settlement to the [pioneer manufacturer] would be $\$ 360$ million (\$1billion $\times 90 \% \times 40 \%) .201$

Additionally, litigation costs or value of services provided by the generic manufacturer would be in addition to the settlement value of $\$ 360$ million. Lastly, "value to the generic [manufacturer] would be determined by the value of consideration received." ${ }^{202}$ Computing expected costs in this or a similar manner will assist in showing that a reverse payment settlement is not anticompetitive.

\section{Time Frame for Generic Entry}

The time frame for the generic manufacturer to enter the market is extremely relevant. ${ }^{203}$ By restricting the generic manufacturer from entering the market, it can be seen as a restraint on output which has generally been seen as anticompetitive. ${ }^{204}$ Moreover, significantly delaying generic entry may provide ammunition to the FTC to satisfy its initial burden under rule of reason analysis. As the Court stated in Actavis, "permitting the patent challenger to enter the market before the patent expires would also bring about competition . . . to the consumer's benefit."205 Allowing generic manufacturers to enter the market before the pioneer manufacturer's patent expires is likely to be seen as

201 Id.

$202 I d$.

203 See In re Lamictal Direct Purchaser Antitrust Litig., 18 F.Supp.3d 560, 570 (D. N.J. 2014) (noting that the generic manufacturer "was allowed six months of early entry").

204 See Nat'l Collegiate Athletic Ass'n v. Bd. of Regents of Univ. of Okla., 468 U.S. 85, 104 (1984).

205 FTC v. Actavis, Inc., 133 S. Ct. 2223, 2234 (2013). 
procompetitive and is directly supported by the HatchWaxman Act because consumers will receive drugs sooner than they would without the settlement. Similarly, reaching a settlement not involving a monetary payment and only allowing the generic manufacturer to enter the market before expiration of the pioneer manufacturer's patent would most likely be procompetitive. 206 Therefore, allowing generic drugs to enter the market sometime before patent expiration is procompetitive.

\section{Strength of Patent}

Pharmaceutical drugs are patentable inventions under patent law. ${ }^{207}$ While the Court in Actavis held that district courts are not necessarily required to litigate the patent's validity before ruling on the reverse payment settlement, 208 the strength of a patent will still be factored into a court's analysis and may indicate anticompetitive harm. ${ }^{209}$ By factoring in the strength of a patent, Actavis supports the Hatch-Waxman Act and the protections afforded through patent law.

Generally speaking, a strong patent refers to one "likely to be found valid and infringed."210 Evidence presented in support of a stronger patent is more likely to indicate the reverse payment settlement is for some other justifiable reason or service, as opposed to the payment being used to keep the generic manufacturer out of the market. On the other hand, a weaker patent may indicate the pioneer manufacturer is using the reverse payment in order to avoid

\footnotetext{
206 Id. at 2237.

207 Patentable inventions are defined as "any new and useful process, machine, manufacture, or composition of matter, or any new and useful improvement." 35 U.S.C. § 101 (2015). Recently, the Supreme Court has addressed the limitations of $\S 101$ and held that items naturally occurring in nature are not patent eligible. Ass'n for Molecular Pathology v. Myriad Genetics, Inc., 133 S. Ct. 2107, 2111 (2013). Furthermore, to be patentable, an invention must be novel, 35 U.S.C. § 102 (2015), and not obvious in the light of prior art, Id. § 103.

208 Actavis, 133 S. Ct. at 2237.

209 Overley, supra note 182.

210 Dickey \& Orszag, supra note 153, at 8.
} 
litigation regarding validity. Subsequently, a settlement "intended to maintain supracompetitive prices and serve as a 'workable surrogate for a patent's weakness" 211 indicates anti-competitive harm.

\section{Venue}

While venue was extremely important before Actavis due to stare decisis, ${ }^{212}$ venue will still be an important factor to consider in the aftermath of Actavis. Venue determines which judicial district a civil action may be brought in. ${ }^{213}$ In Actavis, the Court left it to the lower courts to structure the rule of reason for reverse payment settlement cases. ${ }^{214}$ For example, the Eleventh Circuit may interpret reverse payments under the rule of reason analysis in favor of pharmaceutical manufacturers, as it did before Actavis. With no bright-line rules, some circuits will be more or less restrictive as to what constitutes anticompetitive harm.

Also, most pharmaceutical companies operate on a national or international level. So, common law consistency will be an important factor for pharmaceutical companies in constructing reverse payment settlements. Moreover, common law consistency is important in deciding where to appeal FTC Final Orders since the Appellant can choose the circuit of its choice. Finally, one circuit may quickly develop

211 See In re Lamictal Direct Purchaser Antitrust Litig., 18 F.Supp.3d 560, 570 (D. N.J. 2014) (emphasis added).

212 Compare Valley Drug Co. v. Geneva Pharms., Inc., 344 F.3d 1294 (11th Cir. 2003) with In re K-Dur Antitrust Litig., 686 F. 3d 197 (3d Cir. 2012).

21328 U.S.C. $§ 1391(\mathrm{~b})(1)-(3)$ (2015) (establishing venue in any judicial district where (1) "any defendant resides, if all defendants are residents of the State in which the district is located"; (2) "a substantial part of the events of omissions giving rise to the claim occurred, or a substantial part of property that is the subject of the action is situated"; or (3) "if there is no district in which an action may otherwise be brought as provided in this section, any judicial district in which any defendant is subject to the court's personal jurisdiction with respect to such action").

214 F.T.C. v. Actavis, Inc., 133 S. Ct. 2223, 2238 (2013). 
a robust common law which will be favored among pharmaceutical manufacturers. ${ }^{215}$

\section{Ability to Explain}

All portions of the reverse payment settlement need to be explainable.216 The Court in Actavis emphasized that unjustified payments carry the risk of anticompetitive effects. $^{217}$ Being able to explain why such payment was made will go a long way to rebutting a claim that the payment is anticompetitive. As one suggestion states, "parties should from the outset have a contemporaneous documented explanation for every dollar of each settlement." 218

\section{Policy Recommendation: How REVERSE Payment SETTLEMENTS SUPPORT THE INTENT OF PATENT LAW AND THE HATCH-WAXMAN ACT}

While Congress cannot "overrule" a United States Supreme Court decision, ${ }^{219}$ Congress can pass new laws to effectively overturn a United States Supreme Court decision. ${ }^{220}$ Presently, some critics argue that Congress

215 This may be comparable to the robust common law dealing with corporations in Delaware, which has led many corporations to file their articles of incorporation in the state. See generally LEWIS S. BLACK, JR., Why Corporations CHOOSE DELAWARE (2007), available at http://corp.delaware.gov/whycorporations_web.pdf.

216 See Actavis, 133 S. Ct. at 2237 (stating that a payment which is unexplainable or unjustifiable can indicate anticompetitive harm).

217 Id.

218 Crowell Moring Article, supra note 191.

219 U.S. Const. art III, § 1 ("The judicial Power of the United States, shall be vested in one supreme Court."); Marbury v. Madison, 5 U.S. 137, 177 (1803) ("It is emphatically the province and duty of the judicial department to say what the law is.").

220 See Holmes Grp., Inc. v. Vornado Air Circulation Sys., Inc., 535 U.S. 826 (2002), superseded by statute, 28 U.S.C. $§ 1454$ (a) (2015); City of Mobile, Ala. v. Bolden, 446 U.S. 55 (1980), superseded by statute, Voting Rights Act of 1965, § 2, Pub. L. No. 89-110, 79 Stat. 437 (amended 1982), as recognized in Bartlett v. Strickland, 556 U.S. 1, 10 (2009). 
should outright ban reverse payment settlements. ${ }^{221}$ More importantly, in 2013, Senator Amy Klobuchar introduced PAAGA. ${ }^{222}$ While the present state of PAAGA does not create a per se ban on reverse payment settlements, PAAGA has an anti-reverse payment settlement "taste" and is comparable to the "quick look" analysis previously used by the Third Circuit. ${ }^{223}$ The Court implicitly rejected the presumption of anticompetitive harm in PAAGA by explicitly rejecting the quick-look analysis. ${ }^{224}$ Subsequently, this presumption of anticompetitive harm under PAAGA is contrary to Actavis holding.

Congress should not ban reverse payment settlements or invoke analysis requiring a standard more stringent than Actavis. Instead, Congress should endorse the Actavis framework for analyzing reverse payment settlements. ${ }^{225}$ Actavis provides a middle ground which supports both the intent behind patent law and rationale of the HatchWaxman Act. Under Actavis, motivation for pioneer manufacturers to innovate coexists with the elimination of frivolous patents and allowing generic drugs to reach the market.

To begin with, patent law was designed to "stimulate the efforts of genius" to develop progress in science. ${ }^{226}$ While patent law was not designed to create "private fortunes for the owners of patents," 227 it is undeniable that most people,

221 Ford, supra note 17; see generally Pay-for-Delay, supra note 9. (2013).

222 Preserve Access to Affordable Generics Act, S. 214, 113th Cong.

223 In re K-Dur Antitrust Litig., 686 F.3d 197, 218 (3d Cir. 2012) (holding reverse payment settlements as "prima facie evidence of an unreasonable restraint of trade").

224 FTC v. Actavis, Inc., 133 S. Ct. 2223, 2237 (2013).

225 See Testimony of Jonathan M. Orszag Before the Senate Judiciary Subcomm. on Antitrust, Competition Policy, and Consumer Rights, 113th Cong. 9 (2013) [hereinafter Orszag Testimony] (statement of Jonathan M. Orszag, Senior Managing Director, Compass Lexecon) (stating that Congressional action making reverse payment settlements per se illegal or per se immune to challenges would be counterproductive).

226 Motion Picture Patents Co. v. Universal Film Mfg. Co., 243 U.S. 502, 511 (1917).

227 Id. 
especially corporations which work to maximize shareholder profits, are motivated by economic incentives. This incentive to invent and create, for the progress of science, is so important and widely recognized that it is ingrained in the Constitution. ${ }^{228}$ Moreover, this led the Supreme Court to state:

The economic philosophy behind the clause empowering Congress to grant patents and copyrights is the conviction that encouragement of individual effort by personal gain is the best way to advance public welfare through the talents of authors and inventors in 'Science and useful Arts.' Sacrificial days devoted to such creative activities deserve rewards commensurate with the services rendered. ${ }^{229}$

Actavis keeps this motivation for pioneer manufacturers alive in those settlements not designed to create anticompetitive consequences. If Congress completely eliminates or adversely affects the ability of pioneer and generic manufacturers from entering into such agreements, pioneer manufacturers would be less willing to invest billions of dollars into a drug because it would have a decreased chance of protecting its investment. While consumers would be saving money, it would be at the expense of losing new drugs which may improve health and increase life expectancy. ${ }^{230}$ Consumer health and welfare over the long-term is more important to our society as a whole than short-term economic savings. ${ }^{231}$ As Judge Easterbrook said, "[a]n antitrust policy that reduces prices by 5 percent today at the expense of reducing by 1 percent the annual rate at which innovations lower the costs of patent introduction would be a calamity. In the long run a continuous rate of change, compounded, swamps static

228 U.S. ConsT. art I, $\S 8$, cl. 8 (“To promote the Progress of Science and useful Arts, by securing for limited Times to Authors and Inventors the exclusive Right to their respective Writings and Discoveries.").

229 Mazer v. Stein, 347 U.S. 201, 219 (1954) (emphasis added).

230 See Paul Grootendorst et al., The Life Expectancy Gain

From Pharmaceutical Drugs: A Critical APPRAisal of the LITERATURE 11 (2007) (discussing how pharmaceutical drugs have contributed to increased life expectancy over the past 50 years).

231 Orszag Testimony, supra note 225. 
losses."232 Also, some of the brightest scientists and innovative corporations may not work in or invest in pharmaceutical drugs, a consequence which the Constitution and patent law seek to avoid.

Additionally, the Hatch-Waxman Act attempts to "strike a balance between two competing policy interests: (1) inducing pioneering research and development of new drugs and (2) enabling competitors to bring low-cost, generic copies of those drugs to market." 233 In reality, legislation which in effect works to prohibit reverse payment settlements will contradict the first policy interest behind the Hatch-Waxman Act. Further prohibition "would narrow the patent protection provided to branded manufacturers and, on the margin, reduce incentives to invest in new medicines in the future." 234

The second policy interest, bringing low-cost drugs to the market for consumers, was based in the context that procedures for filing a NDA under the FDCA needed to be revised $^{235}$ because generic companies would not spend time or money to complete the required clinical trials. ${ }^{236}$ Nothing in reverse payment settlements adversely affects this intent to have more generic drugs in the market by revising procedures for filing a NDA. An outright ban on reverse payment settlements would actually increase the time it takes for low-cost drugs to reach consumers. Without the availability of settlements, pioneer and generic manufacturers will be forced to litigate matters on the merits and then wait for the results of any appeals. For example, the FDA blocked a reverse payment settlement

${ }^{232} \mathrm{Id}$. (quoting Frank H. EASTERBROOK, IGNORANCE AND ANTITRUST, IN ANTITRUst, INNOVATION AND COMPETITIVENESS 122-23 (Thomas M. Jorde \& David J. Teece eds., 1992)).

233 Caraco Pharm. Labs., Ltd. v. Forest Labs., Inc. 527 F.3d 1278, 1282 (Fed. Cir. 2008) (quoting Andrx Pharms., Inc. v. Biovail Corp., 276 F.3d 1368, 1371 (Fed. Cir. 2002)).

234 Orszag Testimony, supra note 225.

235 Drug Price Competition and Patent Term Restoration Act of 1984, Pub. L. No. 98-417, 98 Stat. 1585 (1984).

236 Mossinghoff, supra note 20 (citing H.R. REP. No. 98-857, pt. 1 (1984)). 
involving the drug Plavix ${ }^{237}$ which would have allowed the generic drug to reach consumers 10.5 months earlier than it actually did. ${ }^{238}$

Analogous to the Hatch-Waxman Act, the rule of reason, as outlined in Actavis, strikes a balance between protecting manufacturers rights while allowing generic drugs to be brought to the market. For instance, by subjecting reverse payment settlements to the rule of reason, settlements which are not intended to prevent low-cost generic drugs from reaching the market will receive the protections afforded under patent law and those having anticompetitive effects will be struck down. As a result, consumers will no longer be burdened with the effects from anticompetitive settlements.

Analyzing reverse payment settlements under Actavis does not impede upon the rationale of patent law or the Hatch-Waxman Act. To the contrary, it supports these rationales. Therefore, Congress should not act and allow courts to continue analyzing reverse payment settlements under the Actavis framework.

\section{CONCLUSION}

The Supreme Court's correct analysis in Actavis provides a useful and workable framework for practitioners to construct reverse payment settlements and for courts to review such settlements. A per se ban on reverse payment settlements or a presumption of anticompetitive harm would be unsupported by the framers of the Hatch-Waxman Act and simultaneously undermines the important motivations provided through patent law. Actavis, like the Hatch-Waxman Act, is a compromise between consumers and manufacturers by forcing each to give up something in exchange for something else. Consequently, Actavis

237 Plavix is a branded drug, distributed by Bristol-Myers Squibb, prescribed to treat various aliments related to the heart. Medication Guide Plavix ${ }^{\circledR}$ (PLAV-iks) (clopidogrel bisulfate) tablets, FDA.GOV, http://www.fda.gov/downloads/Drugs/DrugSafety/UCM243349.pdf (last visited Nov. 8, 2014).

238 Orszag Testimony, supra note 225. 
2015 Rationale Behind Hatch-WaXman ACt AND Patent LaW 469 provides us with a sound approach to analyzing reverse payment settlements, which should rightly be left undisturbed by Congress. 
